\title{
確率分布をもった型紙による渴水期貯水池群操作
}

\section{Drought-Time Multiple-Reservoir Management with Stochastic Inflow Patterns}

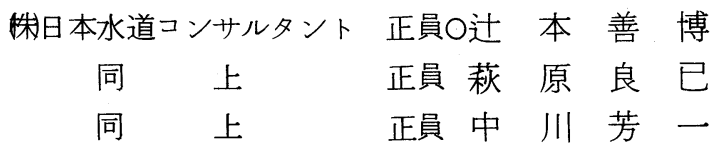

1, はじめに

近年に扣ける都市用水をはじめとした水需要量の急激な增大と、これに対する新規水資源開発の困難性か ら、河川水のより効率的な利用をはかる貯水池群の統合操作が必要とされてきた。貯水池群の統合操作の目 標としては、河川流量の安定供給をはかり、利用可能水量を増大させるとともに、利水システムの安全度の 向上、すなわち渴水時の水不足による被害を减少させることが挙げられる。このことから、利水用貯水池群 の統合操作の問題は、渴水被害を最小とするような貯水池放流量の空間的・時間的配分を決定する最適制御 問題として把えられる。この問題に対してはD P (ダイナミック・プログラミング) の適用が考えられ、 近年では、水資源システムの大規模化に伴 5 計算上の次元や演算時間の増大に対処するため、D P と L P の 合理的瀜合を図ったD C L 手法 ${ }^{1)}$ の開発等新しい研究がなされてきている。

ところで、これらの最適化手法を貯水池運用に有効に利用するためには、将来の貯水池流入量の的確な予 測・設定が肝要となるが、降水現象や流出現象等の不確定性から、その決定論的な予測は非常に困難である。 このため、いくつかの代表的な渴水流況パターンを予測流入量系列として設定する型紙方式 2) 各期の流入 量を確率変数として取り扱い、この確率分布を各期毎に独立飞過去のデータより推定する方法4) が用いられ ることが多い。しかし、前者は確率的な変動の考虑がなされていないこと、また、後者は時系列的な取り扱 いがないことから、いずれの流入量予測設定法にも問題点が残される。

本稿では、この 2 つ方法の問題点を解消する1つの方法として、過去の降水量時系列をその時間変化パ ターンの類似性に注目して分類し、各グループごとに“確率分布をもった型紙”すなわち、貯水池流入量の 確率分布系列を設定するという方法を提示する。

また、この確率分布をもった型紙のもとで貯水池群の最適操作（最適目標放流量系列）を決定するモデル は、確率 D P Kょり定式化した。

そして、モデル流域で、確率分布をもった型紙を設定し、設定した各型紙のもとで各貯水池の最適操作ル ールを決定するとともに、このルールを用いて、大きな渴水を生じた年度の実流入量に対処した運用計算を 行ない、これらの結果を検討する。

2. 貯水池群最適操作モデルの確率 D Pによる定式化

ここでは、まず、貯水池をもつ河川の利水システムのモデル化を行ない、このシステムを貯水池による流 況の確率制御システムとして認識する。ついで、渴水の被害を表わす評価関数を設定し、この評価関数のも とでの最適制御過程を决定する問題を、確率制御システムの多段決定過程の取り扱いに適した手法である確 率 D P により定式化する。そして、この問題の解法のアルゴリズムを述べる。 2-1. モデルの定式化; 図一1反示すよ5に、貯水池 1 と貯水池 2 が並 列に位置し、これらと貯水池 3 が直列の位置関係にある流域を考察の対象 とする。また同図に示した評価地点 1、2 のみで取水するものとする。こ のモデルを貯水池による流況制御システムとして把えれば、入力変数は貯 水池 1 流入量 $I_{1}(t)$ 、貯水池 2 流入量 $I_{2}(t)$ 扎よび残流域流入量 $q(t)$ で あり、これらは確率入力変数である。また状態変数は眝水量 $S_{1}(t) 、 S_{2}(t)$ 、 $S_{3}(t)$ 、決定変数は貯水池目標放流量 $G_{1}(t) 、 G_{2}(t) 、 G_{3}(t)$ 、出力変数は貯

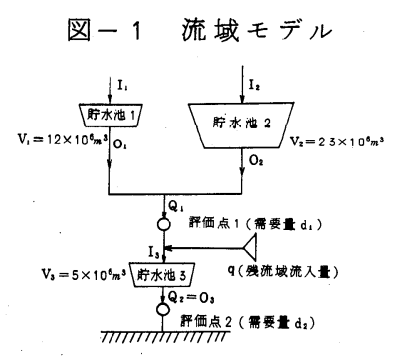


水池実放流量 $\mathrm{O}_{1}(\mathrm{t}) 、 \mathrm{O}_{2}(\mathrm{t}) 、 \mathrm{O}_{3}(\mathrm{t})$ 抢よび評価地点流量 $\mathrm{Q}_{1}(\mathrm{t}) 、 \mathrm{Q}_{2}(\mathrm{t})$ となる。

渴水期貯水池運用計画への確率D P の適用飞際しては、貯水池流入量、残流域流入量の確率変動を考慮し 第 $\mathrm{t}$ 期以後終端をでの渴水被害の和の期待值 $f_{\mathrm{t}}\left(\mathrm{S}_{1} 、 \mathrm{~S}_{2} 、 \mathrm{~S}_{3}\right)$ を最小化するよ 5 亿第 $\mathrm{t}$ 期貯水池目標放流量 を決定するものとし、D P の最適性原理より以下の定式化が行な光る。

$$
\begin{aligned}
& f_{t}\left(S_{1}, S_{2}, S_{3}\right)=\min _{\mathbf{G}(t)} \sum\left\{R(\boldsymbol{Q}(t))+f_{t+1}\left(S_{1}^{\prime}, S_{2}^{\prime}, S_{3}^{\prime}\right)\right\} P_{t}(\mathbb{I}) \\
& \boldsymbol{G}(t)=\left(G_{1}(t), G_{2}(t)\right), \boldsymbol{Q}(t)=\left(Q_{1}(t), Q_{2}(t)\right), \mathbb{I}=\left(I_{1}, I_{2}, q\right)
\end{aligned}
$$

ここに、 $R(\boldsymbol{Q}(t))$ は第 $\mathrm{t}$ 期渴水被害関数值、 $P_{t}(\mathbb{I})$ は第 $\mathrm{t}$ 期飞打ける入力変数 II の確率分布である。 渴水被害関数としては 社会的な渴水被害を示す総合特性值をよく説明していると考えられる5)不足流量の 2 乗和を採用するものとする。

$$
R(\boldsymbol{Q}(t))=\sum_{j=1}^{2}\left(d_{j}(t)-Q_{j}(t)\right)^{2} \quad\left(d_{j}>Q_{i} \text { なる } j \text { につての和 }\right)
$$

また、第 $\mathrm{t}$ 期貯水量 $\mathrm{S}_{\mathbf{i}}(\mathrm{i}=1 、 2 、 3)$ と第 $\mathrm{t}+1$ 期貯水量 $\mathrm{S}_{\mathbf{i}}^{\prime}(\mathbf{i}=1 、 2 、 3)$ の関係扰上び貯水池放流ルー ルは、以下のものを設定している。すなわち、まず貯水池飞招ける第 $\mathrm{t}$ 期の水量連続式は以下の式である。

$$
\mathrm{S}_{\mathbf{i}}^{\prime}=\mathrm{S}_{\mathbf{i}}+\mathrm{I}_{\mathbf{i}}-\mathrm{O}_{\mathbf{i}} \quad(\mathrm{i}=1,2 、 3)
$$

つぎ、、実放流量 $\mathrm{O}_{i}$ は、貯水量 $\mathrm{S}_{\mathrm{i}}$ 、流入量 $\mathrm{I}_{\mathrm{i}}$ 、貯水容量 $\mathrm{V}_{\mathrm{i}}$ 扣よび目標放流量 $\mathrm{G}_{\mathrm{i}}$ 亿よって決まるすのと し、この放流ルール $\mathrm{O}_{\mathrm{i}}=\varphi\left(\mathrm{S}_{\mathrm{i}} 、 \mathrm{I}_{\mathrm{i}} 、 \mathrm{~V}_{\mathrm{i}} 、 \mathrm{G}_{\mathrm{i}}\right)$ を以下のょうに定式化する。

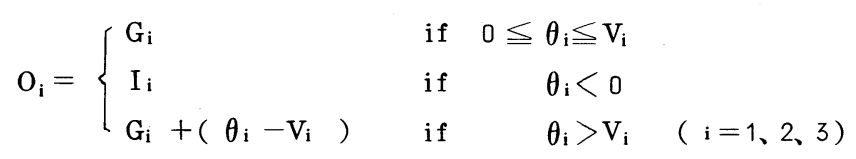

ここで、 $\theta_{\mathbf{i}}$ は、目標放流量を実際に放流するとしたときの仮想貯水量であり、以下の式で求められる。

$$
\theta_{i}=S_{i}+I_{i}-G_{i} \quad(i=1,2 、 3)
$$

すなわち、この放流ルールは眝水池が空のときには、放流量＝流入量、そうでないときには、放流量＝目標 放流量、また满杯のときにはオーバーフローし無効放流が生じるものであり、線形決定ルールと呼ばれる。

以上が確率 D P によるシステムモデルの定式化であるが、このモデルによると各期に打いて、各貯水状態 に応じて最適目標放流量を逐次決定していることとなり、この決定の際には、最終期までの流入量の確率分 布拉よび需要水量の情報を用いていることとなる。このことから、ここで定式化したシステムモデルは、流 況予測を用いたフィードフォワード制御による確率制御システムであると言えよう。

2 - 2. 解法のアルゴリズム; (1)式のような形の関数方程式を解くには、後進型 D P の方法が有効であり、 これによると、各変数を離散化し、数值計算により最終期から出発して 1 期ごとに $f_{\mathrm{t}}\left(\mathrm{S}_{1} 、 \mathrm{~S}_{2} 、 \mathrm{~S}_{3}\right)$ を計算し、 (1)式の右辺の值を最小とするよ5亿目標放流量を決定して いくこととなる。变数の離散化の際には、その離散化単位、 すなわちここでは単位水量として妥当なもので選ぶ必要が ある。単位水量を小さくすれば解の精度は向上するが次元 数が増加し、貯水池の数が多い場合には必要な記憶容量や 演算時間は飛躍的飞增大する。他方、単位水量を大きくし すぎると実用的な解が得られないことも多い。このことか ら、制御時間単位の大きさる自ずと制約を受け、実用的に 見て妥当なものを選ぶ必要がある。な招本稿では時間単位 は旬、単位水量は $10{ }^{6} \mathrm{~m}^{3}$ としている。

つぎに、モデルの解法のアルゴリズムについては、任意 の第 $\mathrm{t}$ 期飞打いて、貯水池の任意の状態 $\left(\begin{array}{lll}\mathrm{S} & \mathrm{S}_{2} & \mathrm{~S}_{3}\end{array}\right)$ 飞打 ける最適目標放流量 $\left(\mathrm{G}^{*} \mathrm{G}_{2}{ }^{*} \mathrm{G}_{3}{ }^{*}\right)$ を決定する補給ルール求 解の部分を図ー2.亿示すにとどめる。

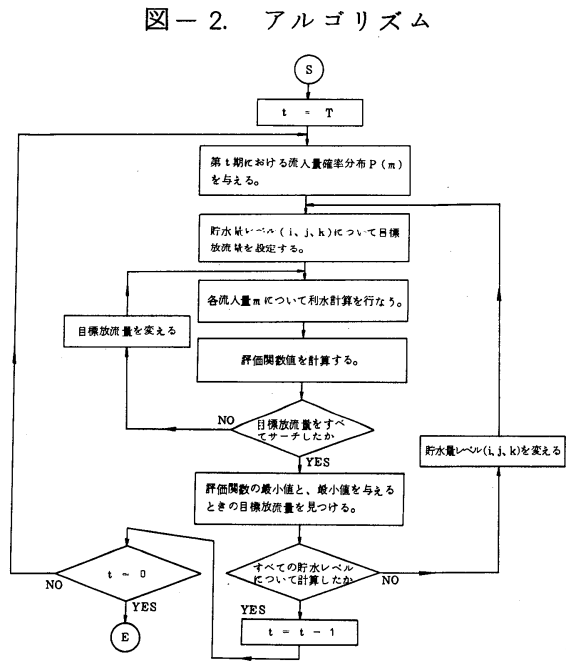




\section{3. 確率分布をもった型紙の設定}

ここでは、図ー1に示したような貯水池群をもつ A川流域をモデル流域として、この流域で大きな渴水が 生じやすい7月～9月の渴水期飞招いて、確率分布をもった型紙の設定を行なら。利水用貯水池群の運用計 算の単位期間としては通常、月、旬、半旬などが用いられることが多いが、ここでは対象期間が渴水期であ ること、打よび $2-2$ で述べた水量の離散化単位を考虑して、単位期間は旬とする。このため、7月上旬か ら9月下旬までの9旬を対象として、貯水池流入量の確率分布の系列を設定することとなる。な打、眝水池 旬流入量は貯水池上流域の旬降水量上り算定されるものと考光、貯水池流入量の確率分布の推定は、旬降水 量の確率分布を推定し、これを変換することにより行なった。

3-1. 降水量の地域相関分析 ; モデル流域とした A川流域には、1 3 ケ所の雨量観測所が存在し、これら

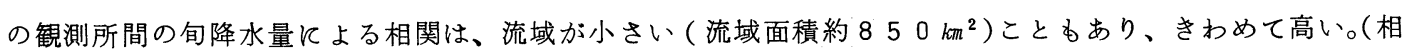
関係数は 0.74 以上となる。）ところで、2.では、眝水池 1、2 の流入量 $I_{1} 、 I_{2} 、$ 打よび残流域流入量 $q$ は 3 変数確率分布 $P_{t}\left(I_{1} 、 I_{2} 、 q\right)$ を形成するねのとして貯水池群最適操作モデルの定式化を行なった。しかし、 各観測所の旬降水量間の相関がきわめて高いととょり、I 、 $I_{2} 、 q$ の間の相関わ高いことが予想される。そこ で、確率 D P の計算時間を短縮するためわあり、 $\mathrm{I}_{2} 、 q は \mathrm{I}_{1}$ の回掃式で表わすこととする。過去 10 年間の 各流入量資料を用いて、 $I_{2}$ 抢よび q を目的変数とし $I_{1}$ を説明変数とする回掃分析を各月（７９月）ごとに 行なった。その結果以下に示す回掃式が得られた。

$$
\begin{array}{lll}
\text { 7月 } & \mathrm{I}_{2}=1.41 \mathrm{I}_{1}+0.9(0.93) 、 & \mathrm{q}=1.40 \mathrm{I}_{1}+0.9(0.59) \\
\text { 8月 } & \mathrm{I}_{2}=1.80 \mathrm{I}_{1}-0.8(0.94) 、 & \mathrm{q}=3.20 \mathrm{I}_{1}-3.0(0.85) \\
\text { 9月 } & \mathrm{I}_{2}=1.20 \mathrm{I}_{1}+0.1(0.96) 、 & \mathrm{q}=1.10 \mathrm{I}_{1}+1.0(0.72)
\end{array}
$$

ここに、（）内の数值は相関係数である。こ5して、(7)式の回掃式を用いることにより、確率入力変数は

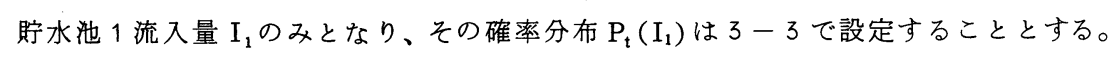

3-2. 旬降水量時系列パターンの分析; ここでは、眝水池 1 上流域の旬降水量時系列を、その時間変化ハ ターンの類似性に注目して分類する。そのため、各年度の旬降水量時系列をサンプル（サンプル数５９）と し、各旬の降水量を特性值 (特性值数9) として主成分分析の)を行なった。 その結果、表一１亿示すような固有值、寄与率、因子負荷量を示す主成分が 抽出された。これらの主成分の 5 ち比較的寄与率の大きい第 1 、第 2 主成分 $\left(Z_{1} 、 Z_{2}\right)$ の因子得点の正負によりサンプルをI I I の 4 群に分類し、各群 の平均旬降水量時系列を図ー 3 亿示す。ここに、各群の降水量時系列パター ンの特徴は以下のようである。

I 群 $\left(Z_{1}>0 、 Z_{2}>0\right) \cdots 7$ 月上旬の降水量は非常に多いが、8月、9月 の降水量は9月上旬を除き少ない。

表-1 固有值、寄与率、 因子負荷量

II 群 $\left(Z_{1}<0 、 Z_{2}>0\right) \cdots$ 時間変化が小さく、7 月中旬と9月上旬で降水 図一 3. 平均旬降水量時系列

量が少ないのを除き平均的。

群 $\left(Z_{1}<0 、 Z_{2}<0\right) \cdots 7$ 月から 8 月上旬飞かけての降水量は少ないが、 8 月下旬拈上び9月中、下旬の降水量が多い。

$\mathbb{N}$ 群 $\left(Z_{1}>0 、 Z_{2}<0\right) \cdots 7$ 月と9 月上、中旬、と<k9月中旬の降水量 が多い。他は平均的。

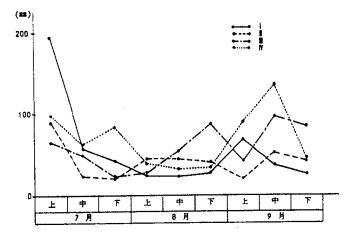

3-3. 旬降水量の確率分布の推定；3ー2 で分類した 4 パターン(群)の各パターンに含まれるサンプル

(旬降水量時采列) 数は、それぞれ16、13、16、14であり、これらのサンプルをるとに、各旬ごとに、 降水量の確率分布を推定する。パターンごとに各旬の降水量の頻度分布を描くと、分布形としては、対数正 規分布が適合するよらであった。そこで、以下では、旬降水量の確率分布を対数正規分布とみなし、各旬ご とに岩井法により定数 $\mathrm{b} 、 \mathrm{a} 、 \mathrm{r}_{0}$ を推定した。推定結果を表ー 2 亿示す。 
な招、bはすべてのパターン、旬で0であった。

ここK、 $\mathrm{b} 、 \mathrm{a} 、 \mathrm{r}_{0}$ は、旬降水量を $\mathrm{r}$ として、

$$
\xi=\mathrm{a} \cdot \log (\mathrm{r}+\mathrm{b}) /\left(\mathrm{r}_{0}+\mathrm{b}\right)
$$

で定義される $\xi$ が、N（0、1）の正規分布をするとした きの変換定数である。

表一2 パターン別旬降水量分布定数

\begin{tabular}{|c|c|c|c|c|c|c|c|c|c|c|}
\hline \multirow{2}{*}{$\begin{array}{l}\text { அタ } \\
\text {-ン }\end{array}$} & \multirow{2}{*}{$\begin{array}{l}-5 x \\
-8\end{array}$} & \multicolumn{3}{|c|}{7 月 } & \multicolumn{3}{|c|}{8 月 } & \multicolumn{3}{|c|}{9 月 } \\
\hline & & 上 & 中 & T & 上 & 中 & 下 & 上 & 中 & 下 \\
\hline I & $\begin{array}{l}\mathrm{a} \\
\mathrm{r}_{0}\end{array}$ & $\begin{array}{r}3.75 \\
180.1\end{array}$ & $\begin{array}{c}0.82 \\
20.5\end{array}$ & $\begin{array}{c}0.81 \\
16.2\end{array}$ & 11.26 & $\begin{array}{r}1.26 \\
11.6\end{array}$ & $\begin{array}{c}17.06 \\
17.5\end{array}$ & $\begin{array}{r}2.04 \\
52.2\end{array}$ & $\begin{array}{c}1.1 .7 \\
20.8\end{array}$ & $\begin{array}{r}1.17 \\
14.6\end{array}$ \\
\hline II & $\begin{array}{l}a \\
r_{0}\end{array}$ & 57.31 & $\begin{array}{l}0.81 \\
7.81\end{array}$ & $\begin{array}{l}0.80 \\
7.5\end{array}$ & $\begin{array}{r}1.31 \\
25.9\end{array}$ & $\begin{array}{c}1.07 \\
21.6\end{array}$ & $\begin{array}{r}2.46 \\
32.8\end{array}$ & $\begin{array}{c}0.99 \\
11.0\end{array}$ & $\begin{array}{r}25.1 \\
43.9\end{array}$ & $\begin{array}{r}1.43 \\
26.5\end{array}$ \\
\hline I & $r_{0}$ & 52.61 & $\begin{array}{c}0.73 \\
17.3\end{array}$ & $\begin{array}{l}0.77 \\
5.4\end{array}$ & $\begin{array}{c}0.83 \\
10.3\end{array}$ & $\begin{array}{c}152 \\
35.5\end{array}$ & $\begin{array}{c}1.85 \\
6.6 .7\end{array}$ & $\begin{array}{r}1.55 \\
29.6\end{array}$ & $\begin{array}{l}2.98 \\
83.6\end{array}$ & $\begin{array}{c}1.89 \\
64.3\end{array}$ \\
\hline N & $\begin{array}{l}a \\
r_{0}\end{array}$ & $\begin{array}{c}1.46 \\
67.5\end{array}$ & $\begin{array}{r}1.40 \\
40.7\end{array}$ & $\begin{array}{r}0.94 \\
38.0\end{array}$ & $\begin{array}{r}2.14 \\
14.0\end{array}$ & $\begin{array}{l}0.87 \\
6.85\end{array}$ & $\begin{array}{c}1.24 \\
20.2\end{array}$ & $\begin{array}{c}1.92 \\
69.9\end{array}$ & 118.16 & $\begin{array}{c}0.90 \\
19.6\end{array}$ \\
\hline
\end{tabular}

3ー4. 確率分布をもった型紙の設定；3ー3.で推定したパターンごとの旬降水量確率分布系列を、貯水池 流入量の確率分布采列に変換することにより、確率分布をもった型紙を設定することとする。

降水量を入力として流出量（貯水池流入量）を推定する （長期）流出モデルには、タンクモデルをはじめとして種 々のものがあるが、ここでは、単位期間が旬ということも あり、流出特性を流出率で代表させることとする。

すなわら、貯水池旬流入量 I は、貯水池上流域旬降水量を $\mathrm{r}$ として、 I $=\mathrm{A} ・ \mathrm{f} \cdot \mathrm{r}$

で与えられるものとした。ここに、 $\mathrm{A}$; 集水面積、 $\mathrm{f}$; 流 出率である。この(9)式を用いて、表一 2 亿その分布定数を 示したパターンごとの各旬降水量の確率分布を貯水池流入 量の確率分布 $\mathrm{P}\left(\mathrm{I}_{1}\right)$ 飞変換した。こうして、7月上旬か 59月下旬までの各旬の貯水池流入量の確率分布の系列が、 3ー2で分類した 4 つの各パターンについて得られた。こ れらを、それぞれ、確率分布をもった型紙 I ～IN とし、図 - 4 に示す。

\section{4. 最適操作モデルの適用}

ここでは、2.で定式化した貯水池群最適操作モデルを、A川流域の 3 貯水池 (図ー1参照) 飞適用し、3. で設定した 4 種の確率分布をもった型紙（以下、単に型紙と記す）のもとでの各貯水池の最適操作ルールを 算定するとともに、平均的実流入量系列扣よび大きな渴水の生じた年度での実流入量系列に対し、この最適 操作ルールによる貯水池の運用計算を行ない、それらの結果を検討する。

4-1. 演算条件扣よび入力データ；前述したよ５に、モデルの運用期間は7〜9月の3ケ月（９旬）とし、 操作の時間単位は旬とする。このため、水量の離散化単位は少なくとも評価地点での旬需要量の最小値程度 は必要であり、また、2.で述べたように、貯水池での離散化が大型電算機の容量を越えないことが要求され る。以上のことから、ここでは、評価地点の旬需要量扎よび貯水池容量が $\mathrm{V}_{1}=12 \times 10^{6} \mathrm{~m}^{3} \mathrm{~V}_{2}=23 \times 10^{6} \mathrm{~m}^{3}$ $\mathrm{V}_{3}=5 \times 10^{6} \mathrm{~m}^{3}$ であることを考虑して、水量の離散化単位 $\Delta \mathrm{S}$ を $10^{6} \mathrm{~m}^{3}$ と設定した。この離散化単位による と、貯水池 1、2、3の容量はそれぞれ整数で12、23、5 となる。つぎに、各流入量に関しても同一の単位で

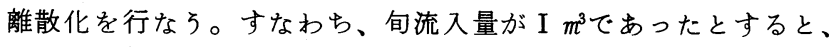

$$
(m-1 / 2) \cdot \Delta \mathrm{S}<\mathrm{I} \leqq(m+1 / 2) \cdot \Delta \mathrm{S}
$$

を满たす整数 $m$ を離散化された流入量とする。

以上の演算条件を表一 3.রをとめる。 表 -4 評価地点需要量 $\left(\times 10^{6} \mathrm{~m}^{3}\right)$ また、評価地点 $1 、 2$ に扣ける各期の需 要量 $d_{i}(t)$ を表一 4 亿示す。

4 -2. 最適操作ルールの決定；2.で定

\begin{tabular}{|c|c|c|c|c|c|c|c|c|c|}
\hline \multirow{2}{*}{ 旬 } & \multicolumn{3}{|c|}{7 月 } & \multicolumn{3}{c|}{8 月 } & \multicolumn{3}{|c|}{9 月 } \\
\cline { 2 - 11 } 地点 & 上 & 中 & 下 & 上 & 中 & 下 & 上 & 中 & 下 \\
\hline 1 & 8 & 8 & 9 & 8 & 8 & 9 & 8 & 8 & 7 \\
\hline 2 & 2 & 2 & 2 & 2 & 2 & 2 & 2 & 2 & 2 \\
\hline
\end{tabular}

式化した貯水池群最適操作モデルは、入力すなわち貯水池流入量を確率変数としたため、最終期までの最適 目標放流量系列を一意的飞定めるものではなく、各期 $\mathrm{t} （ \mathrm{t}=1 、 \cdots 、 \mathrm{~T})$ 飞打ける貯水池群の貯水状態 $\mathbb{S}(t)=\left(S_{1}(t) 、 S_{2}(t) 、 S_{3}(t)\right)$ のそれぞれについて各貯水池の最適目標放流量 $G(t)=\left(G_{1}(t) 、 G_{2}(t) 、 G_{3}(t)\right)$ 
を決定するモデルである。すなわち、 $\mathrm{t}$ 期の最適目標放流量 $\mathrm{G}(\mathrm{t})$ は、その期の各貯水池眝水量 $\mathbb{S}(\mathrm{t})$ の全ての 組み合せの各々についてひとつずつ決定されるものである。

貯水池 1 流入量 $\mathrm{I}_{1}$ の確率分布 $\mathrm{P}_{\mathrm{t}}\left(\mathrm{I}_{1}\right)$ を型紙 $\mathrm{I} \sim \mathrm{IV}$ とした場合のそれぞれについて、最適操作ルール、す なわち各期の貯水池群の貯水状態 $\mathbb{(}(\mathrm{t})$ 亿応じた最適目標放流量 $\mathrm{G}(\mathrm{t})$ を算定した結果を表 -5 、図-5、図一6に示す。

表-5 (1)(2) 亿は、型紙 I のもとでの 8 月中旬の貯水池1、表-5 型紙 $I$ のもとでの $G_{1} 、 G_{2}$ （ 8 月中旬） 2 の目標放流量 $G_{1} 、 G_{2}$ 老、貯水池 $1 、 2$ の各貯水状態飞つ いて示した。な技貯水池 3 の貯水量 $\mathrm{S}_{3}$ は(1)では満水、(2)で は0としている。

目標放流量 $\mathrm{G}_{1} 、 \mathrm{G}_{2}$ は、各貯水池貯水量 $\mathrm{S}_{1} 、 \mathrm{~S}_{2} 、 \mathrm{~S}_{3}$ に上り 大きく変わるが、全般的にみて、貯水池容量の大きい眝水 池 2 の目標放流量 $\mathrm{G}_{2}$ は、貯水池 1 の目標放流量 $\mathrm{G}_{1}$ 上りも大 きい。また、 $\mathrm{G}_{1}$ は $\mathrm{S}_{1}$ が大きくなるに従って增加するが、逆 K $\mathrm{S}_{2} 、 \mathrm{~S}_{3}$ が大きくなるに伴い小さくなる傾向があり、 $\mathrm{G}_{2}$ は $\mathrm{S}_{2}$ が大さくなるに従って増加するが、 $\mathrm{S}_{1} 、 \mathrm{~S}_{3}$ K対して はその増加に伴い减少する傾向がみられる。 な打、他の旬怙よび型紙々ついても同様のことが言える。

(1) $\left(\mathrm{S}_{3}=\mathrm{V}_{3}\right)$

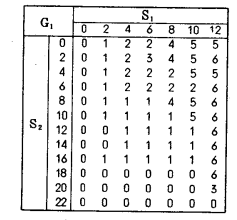

(2) $\left(\mathrm{S}_{3}=0\right)$
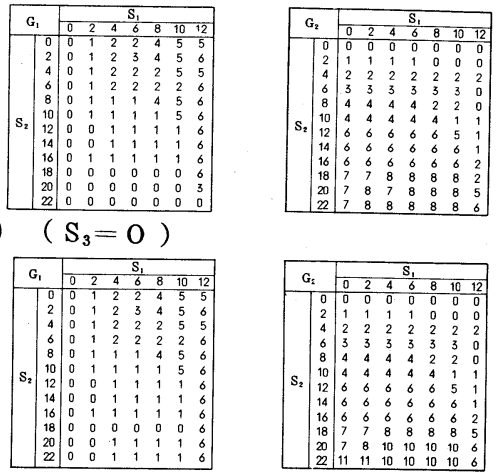

図一 5 貯水池 2 最適目標放流量

図-5(1)、(2)飞は、各型紙のもとでの貯水池 1 打 よび貯水池 3 の貯水状態を一定としたときの貯水池 2 貯水量 $S_{2}$ に応じた目標放流量 $G_{2}(t)$ を示し、また 図一 6(1) - (4) そは、各型紙のぬとでの $G_{1}(t) と G_{2}(t)$ との和の系列を、 4 種類の貯水状態について示した。 これらの図ょの、型紙の違いによる目標放流量の相 異を検討する。

目標放流量は、 $\mathrm{S}_{1} 、 \mathrm{~S}_{2} 、 \mathrm{~S}_{3}$ が大きい場合は、型紙 により大きく異なる。すなわち、 $\mathrm{S}_{1} 、 \mathrm{~S}_{2} 、 \mathrm{~S}_{3}$ が全て
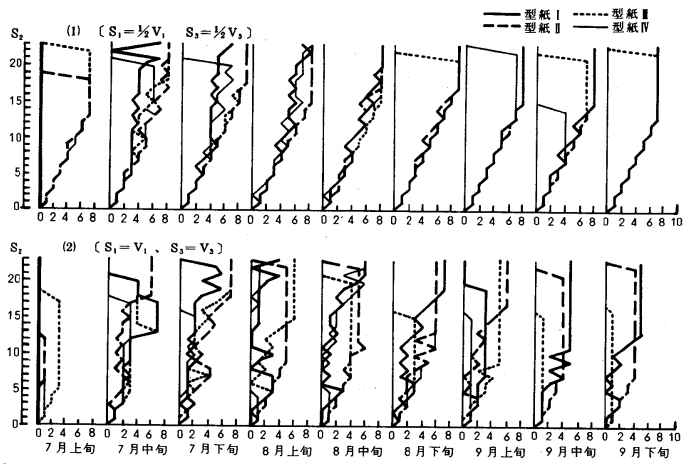

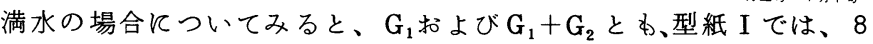
月拈よび9月中、下旬で大きくなって拈り、それ以外の旬では0で ある。また、型紙 II では、7月中、下旬打よび 8 月下旬、9月上旬 で、型紙 は、8月で、 $\mathrm{G}_{1}$ ならびそ $\mathrm{G}_{1}+\mathrm{G}_{2}$ が大さい。このような目標放流量 系列の変動を、図一 4 亿示す型紙の貯水池流入量の確率分布系列と 比較すると、各型紙について、流入量の確率分布が小さい方に偏っ ている旬の目標放流量が大きくなっている。これは、大きな流入量 の期待できるときとは、目標放流量を0として子(眝水位が满水の ため)オーバーフローにより需要をまかなえるのに対し、小さな流 入量しか期待できないときには、目標放流量を大きくして需要に対 処する必要があるためと考兄られる。一方、 $\mathrm{S}_{1} 、 \mathrm{~S}_{2} 、 \mathrm{~S}_{3}$ が小さい場 合、は、目標放流量の型紙による差異は小さくなるととわに、旬間 の変動わ小さくなる。すなわら、極端飞大きな貯水池流入量が期待
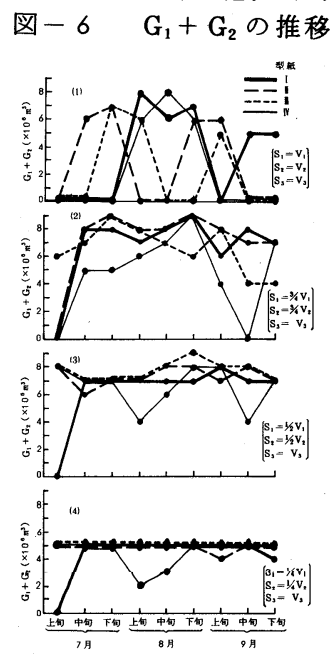
でき、オーバーフローにより需要がまかなえる旬（型紙Ｉ９７月上旬、IVの9月中旬）や、逆に、極端飞小 さな流入量しか期待できず、放流を行なえば以後の貯水池運用に支障をきたすような旬（型紙 II の9月上旬、 IVの 8 月上、中旬）での目標放流量が小さく押兄られる以外は、目立った変動がなくなる。このことより、 
各旬の流入量の確率分布の変動の小さい型紙 II 、IIでは、目標放流量わ各旬間でほとんど変化しない。 4 -3. 貯水池群運用結果とその考察； 4 - 2.で考察したよ5に、眝水池群の最適操作ルールは、流入量の 確率分布の系列としてどの型紙を用いるかにより大きく異なる。そこで、ここでは型紙の違いによる貯水池 群運用結果の相異を検討するために、各型紙の平均流入量系列を実流入量系列とした場合の運用計算、扣よ び実際に大きな渴水を生じた年度の実流入量系列に対する運用計算を行なった。表一 6 評価関数值

まず、各型紙の平均流入量系列を実流入量系列とした場合の各々について、各 型紙のぬとでの操作ルールにより貯水池群の運用を行なった結果の評価関数值、 すなわち、不足流量の 2 乗和を表一 6 亿示す。

これをみると、貯水池群の運用結果は、どの操作ルールを用いるかによって大 きく異なり、実流入量系列と同じ型紙のるとでの操作ルールを用いた場合の評価 関数值が、他の型紙のぬとでの操作ルールを用いた場合に比べて著しく小さい。

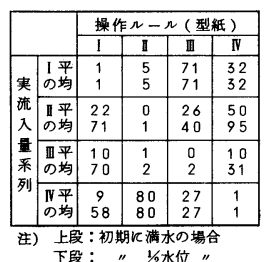

表一 7 渴水年実流入量系列

つぎ、表一 7 亿示すような、大きな渴水を生じた年度の実流入量系列 に対して、型紙 I〜INのぬとでの貯水池群運用を行なった結果を、表一8 表一 9 亿示す。表- 8 亿は、各貯水池の目標放流量系列拈よび各評価地点 での不足水量を、また、表一9 亿は評価関数值 (不足水量 2 乗和)を示す。

これをみると、実流入量采列は、7月から8月中旬飞かけてきわめて小 さいにわかかわらず、型紙 I、I、Nのルールでは、7月の目標放流量が 小さく押兄られて打り、大きな不足水量が生 じている。これに対し、この期間に小さな流 入量しか期待しない型紙 II ルールでは、目 標放流量が大きくとられ、不足水量は小さい。 その結果、8月、9月の不足水量は、他の型 紙のルールに較ベやや大きいわのの、不足水 量が各旬飞分散され、評価関数值ははるかに 小さくなっている。

最後に、型紙 II のルールを用いたときの各 貯水池貯水量の変化を、図ー 7 亿示す。

5. おわりに ( 渴水年実流入量采列)

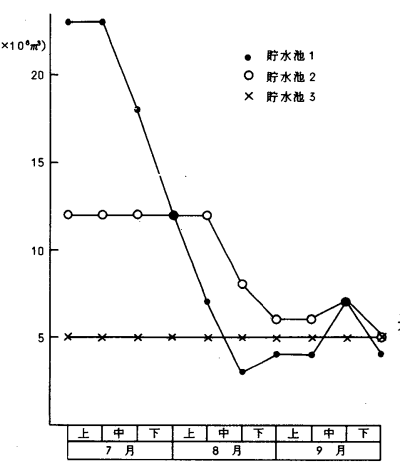

表一 8 目標放流量、不足水量 （渴水年実流入量系列）

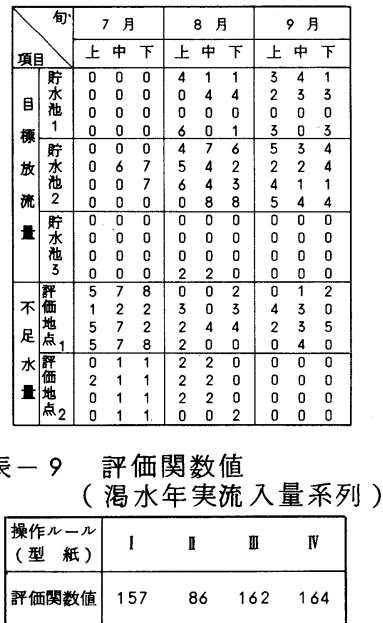

渴水時の水不足による被害の減少をはかる眝水池群の統合操作の問題は、評価関数としての渴水被害を最 小とするような貯水池放流量の空間的・時間的配分を決定する最適制御問題として把兄られるが、このとき 将来の貯水池流入量采列としてどのようなわのを予測・設定するかが大きな問題となる。このため、本稿で は、確率分布をわった型紙として、時采列特性を考虑した流入量の確率分布系列を設定することを考觉た。

まず2.で、渴水期の利水用貯水池群の最適操作ルールを、渴水時の被害の最小化とい5評価基準のおとで 決定するモデルを確率 D P に上り定式化した。ついで3.では、モデル流域の過去の降水量時系列を、その時 間変化パターンの類似性に注目して分類し、各グループごとに各期の降水量の確率分布を推定することによ り、確率分布をぬった型紙の設定を行ない、4.では、これらの型紙のぬとでの最適操作ルールを決定すると とるに、実流入量采列に対し、この最適操作ルールによる貯水池群の運用計算を行なった。

この結果、どの型紙を用いるか、すなわち、将来の流入量の確率分布系列をどのようなねのとして設定す るかにより、操作ルールや運用結果が大き、く異なり、将来流入量系列の予測・設定の重要性が確認された。

(参考文献]1) 竹内；土木学会論文報告集２２２号２）西原；洪水予報、全日本建設技術協会
3) 中村；土木研究所土木技術資料 $18-8$
4 ）萩原・中川・辻本；土木学会第 33 回年講 II -37

$5 ）$ 萩原・中川・森；土木学会第 33 回年講 $I N-140$

6）たと兊ば奥野他；多変量解析法、日科技連 